\title{
Management Success Factors in Managing Restaurant Businesses
}

\author{
Ian Nurpatria Suryawan \\ Trisakti School of Management, Management Program \\ Email: \\ ian.nurpatria@gmail.com
}

\begin{abstract}
Restaurant business owners seek to improve their management by analyzing in restaurant business management in Jakarta, Surabaya, Semarang, Bandung, Tangerang and Bekasi. The problem of this research is to find out what factors influence organizational performance. The population of this study were all restaurant business owners (both local and international cuisine) in Jakarta, Surabaya, Semarang, Bandung, Tangerang and Bekasi. The research method used is using non-probability sampling techniques with purposive sampling method. The number of samples was 421 respondents. The results or findings of this study show that there are 4 research hypotheses, namely the positive influence of dynamic capabilities on organization innovation with an alpha of $10 \%$, the positive influence of organization slack on organization performance with an alpha of 5\%, the positive influence of organization performance on organizaton performance with an alpha of 5\%, Positive influence of dynamic capabilities on organizational performance mediated by organization innovation with alpha 10\%. For the other 9 hypothesis testing resulted in unproven conclusions.
\end{abstract}

Keywords: managing restaurant businesses.

Abstrak: Pemilik usaha restoran berupaya membenahi manajemennya dengan melakukan analisis pada pengelolaan usaha restoran di Jakarta, Surabaya, Semarang, Bandung, Tangerang dan Bekasi. Masalah dari penelitian ini adalah mencari tahu faktor-faktor apa saja yang mempengaruhi kinerja organisasi. Populasi dari penelitian ini adalah seluruh pemilik usaha restoran (baik masakan asli daerah maupun masakan internasional) di Jakarta, Surabaya, Semarang, Bandung, Tangerang dan Bekasi. Metode penelitian yang digunakan yaitu menggunakan teknik non-probability sampling dengan metode purposive sampling. Jumlah sampel sebanyak 421 responden. Hasil atau temuan penelitian ini memperlihatkan terdapat 4 hipotesis penelitian yaitu pengaruh positif dari dynamic capabilities terhadap organization innovation dengan alpha $10 \%$, pengaruh positif dari organization slack terhadap organization performance dengan alpha 5\%, pengaruh positif dari organization performance terhadap organizaton performance dengan alpha 5\%, pengaruh positif dari dynamic capabilities terhadap organizational performance yang dimediasi oleh organization innovation dengan alpha 10\%. Untuk 9 hipotesis pengujian lainnya menghasilkan kesimpulan tidak terbukti.

Kata kunci: managing restaurant businesses. 


\section{INTRODUCTION}

The current world development makes restaurant business competition increasingly growing and changing rapidly, so that organizations must be able to adapt to the current business environment (Turulja and Bajgoric, 2018). Restaurant management also tries to provide the best service quality for its customers, namely how to manage the restaurant business as well as possible. Restaurants must be able to adapt to the rapid development of information technology and a dynamic environment, so the taste of food must be able to determine strategic changes in responding to market demand and competition (Wu et al., 2011). Advances in technology have made competition in the restaurant service industry tighter after more and more restaurants.

To make a restaurant able to present appropriate food tastes and bring customer loyalty, knowledge management is needed which plays an important role in increasing organizational resources because it can measure organization performance accurately (Turulja and Bajgoric, 2018). Knowledge management also has an influence on organizational innovation because restaurants that have experience in knowledge management can provide increased organizational performance because they have been diligent in learning, are open and have a vision (Kumaravel and Vikkraman, 2018).

Competitive intensity tries to explain the restaurant business that is facing a competitive environment and the resulting results through the innovations that have been made so as to increase the organization performance of the restaurant (Idarraga and Marin, 2019). In highly competitive conditions, restaurant management will use its resources and knowledge to avoid risk, uncertainty and other factors so as to increase organization performance.

Dynamic capabilities are the ability of restaurant management to make changes in an unstable environment and productively use available resources to produce innovations (Labanauskè and Nedzinskas, 2017). All of which require a change into something new and combined into one thing in the customer service process by restaurant management called dynamic organizational innovation (Najmi et al., 2018) so that organizational performance is maximized (Turulja and Bajgoric, 2018).

Organizational slack explains the ability of restaurant management to have the capacity to survive and be able to adapt to changes in the environment so that it has a positive effect which in turn can improve organizational performance (Idarraga and Marin, 2019).

As for the factors already mentioned, the success of restaurant management in managing a restaurant business is related. In this case, organizational performance regarding services has been studied in Yemen (Mutahar et al., 2017) and in Ethiopia (Shiferaw, 2018). 


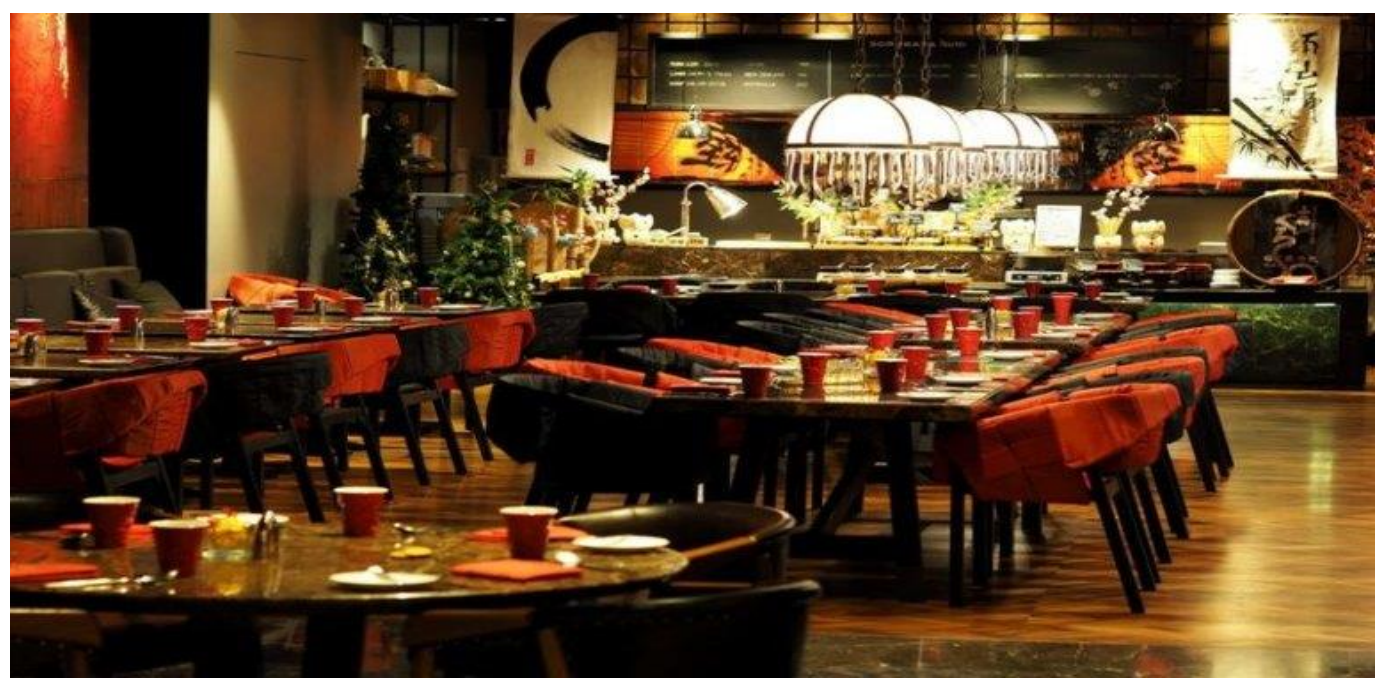

Figure 1. Restaurant businesses

Source: (https://www.posist.com/restaurant-times/restro-gyaan/9-essential-traits-successfulrestaurant.html/2020)

Research Purposes. This study has the objectives: (1) To analyze and determine the positive influence of knowledge management on organization innovation in a restaurant business, (2) To analyze and determine the positive effect of competitive intensity on organization innovation in restaurant businesses, (3) To analyze and determine the positive effect of dynamic capabilities on organization innovation in restaurant businesses, (4) Analyzing and knowing the positive influence of organizational slack on organization innovation in restaurant businesses, (5) Analyzing and knowing the positive influence of knowledge management on organization performance in restaurant businesses, (6) Analyzing and knowing the positive influence of competitive intensity on organization performance in restaurant businesses, (7) Analyzing and knowing the positive influence of dynamic capabilities on organization performance in restaurant businesses, (8) Analyzing and knowing the positive influence of organizational slack on organizational peers. performance in a restaurant business, (9) Analyzing and knowing the positive effect of organization innovation on organization performance in a restaurant business, (10) Analyzing and knowing the positive influence of knowledge management on organization performance mediated by organization innovation in a restaurant business, (11) Analyzing and knowing the effect positive competitive intensity on organization performance mediated by organization innovation in restaurant businesses, (12) Analyzing and knowing the positive influence of dynamic capabilities on organization performance mediated by organization innovation in restaurant businesses, (13) Analyzing and knowing the positive influence of organizational slack on mediated organization performance organization innovation in restaurant business. 


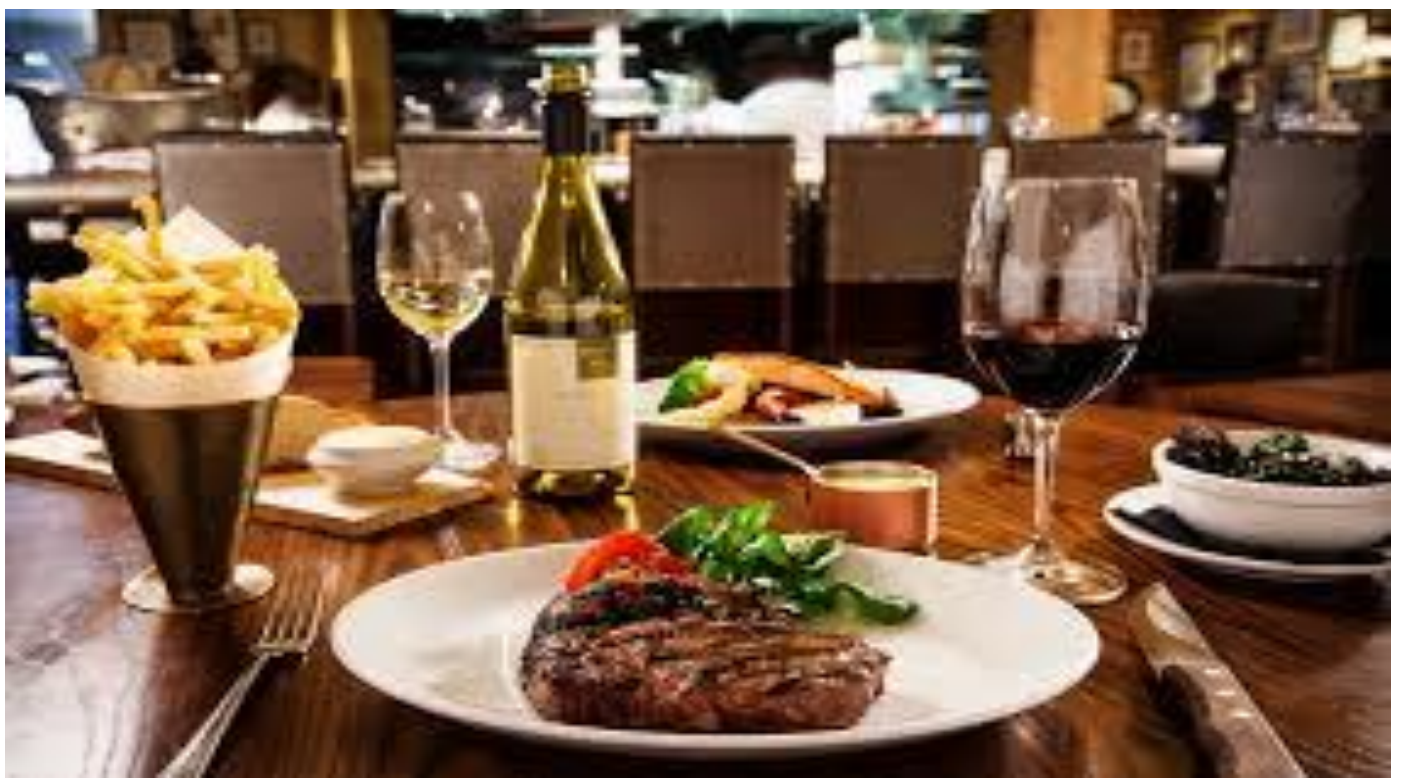

Figure 2. Restaurant businesses

Source: (https://lifestyle.okezone.com/2020)

\section{THEORETICAL REVIEW}

The influence of knowledge management with organization innovation. Knowledge management is a series of business activities carried out by restaurant managers that are relatively aimed at increasing knowledge, practices related to knowledge, behavior and decisions from management and restaurant management performance in presenting good and expected food tastes (King, 2009). Knowledge management is the ability of restaurant business management to absorb knowledge and process it and produce dishes that match the tastes of customers so that organizations have a role for knowledge management in every innovation made by management (Alsabbagh and Khalil, 2017). On the other hand, a management attitude is something that reflects a professional person who is someone who can do work based on knowledge, skills and attitude to become a source of income and can achieve the quality standards required by management (Ganguly et al., 2019) (Ngoc-Tan and Gregar, 2018).

Based on the foregoing, a hypothesis is made:

$\mathbf{H}_{1:}$ Knowledge management has effect on organization innovation.

The influence of competitive intensity with organization innovation. Management utilizes resources in the form of experience and accumulated knowledge to innovate in the restaurant business so that it can avoid the risk of loss and uncertainty (Idarraga and Marin, 2019). Restaurant management also strives to produce high innovation in order to achieve a sustainable competitive intensity against its competitors, so that management can produce optimal organization performance (Haryanto et al., 2019). 
Based on the foregoing, a hypothesis is made:

$\mathbf{H}_{2}$ : Competitive intensity has effect on organization innovation.

Influence dynamic capabilities with organization innovation. Dynamic capabilities are restaurant management's ability to make changes in an unstable organizational environment as a result of restaurant business competition and productively use existing organizational resources to produce an innovation towards change in a better direction in accordance with the mission and vision set by management restaurants (Labanauske and Nedzinskas, 2017).

Based on the foregoing, a hypothesis is made:

H3: Dynamic capabilities has effect on organization innovation.

The influence of organizational slack with organization innovation. Organizational slack is all the resources owned by restaurant management to meet the demands of subunits in the organization that require additional resources to complete the tasks set by management (Idarraga and Marin, 2019).

Based on the foregoing, a hypothesis is made:

H4: Organizational slack has effect on organization innovation.

The influence of knowledge management with organization performance. Knowledge management can provide an increase in organizational performance owned by restaurant management because restaurant management members have been diligent in learning, are open and want to follow the vision determined by management (Kumaravel and Vikkraman, 2018) (Turulja and Bajgoric, 2018). Knowledge management is important to increase the resources owned by restaurant management (Abdullah et al., 2013).

Based on the foregoing, a hypothesis is made:

H5: Knowledge management has effect on organization performance.

The influence of competitive intensity with organization performance. The high intensity of competition experienced by restaurant management can be overcome by using innovation to avoid cooking obsolescence and proactively anticipating market changes so as to enrich and expand the reach of food marketing, increase market position and maximize the number of restaurant customers (Abebe and Angriawan, 2014) (Idarraga and Marin, 2019).

Based on the foregoing, a hypothesis is made:

H6: Competitive intensity has effect on organization performance.

Influence dynamic capabilities with organization performance. (Najmi et al., 2018) conducted an analysis that dynamic capabilities are the ability of restaurant management to make changes in an unstable environment and productively use available resources so that they can produce better organizational performance and are expected by restaurant management. 
Based on the foregoing, a hypothesis is made:

H7: Dynamic capabilities has effect on organization performance.

The influence of organizational slack with organization performance. (Idarraga and Marin, 2019) say organizational slack is the excess resources owned by restaurant management to meet certain levels of production because it responds to internal organizational pressure, in accordance with changes in strategy. For this reason, in facing environmental forces that have an impact on banking, an organization slack can be used to improve organization performance (Idarraga and Marin, 2019). (Idarraga and Marin, 2019) have proven through the results of their research that organizational slack has a positive and significant effect on innovation, for this reason restaurant management is expected to invest excess resources in short and long term innovation programs. This results in better innovation thanks to the resources needed to acquire, adapt and enhance the taste of cuisine, and represents that innovative activities are developed by restaurant management.

Based on the foregoing, a hypothesis is made:

H8: Organizational slack has effect on organization performance.

The influence of organization innovation with organization performance. Good management of the restaurant business is needed so that employee performance can be maximized, so innovation from restaurant management is needed to improve employee performance (Alawamleh et al., 2018). Organizational structures that are properly and appropriately arranged in accordance with the mission and vision of the restaurant can influence the improvement and achievement of required innovations, thereby affecting restaurant performance well (Alawamleh et al., 2018). The influence on employee performance and its effect on overall restaurant performance is by placing a recommendation perspective to ensure orientation in the restaurant business environment. (Alawamleh et al., 2018). Furthermore, he said, to understand the talents and creativity of employees in order to innovate cuisine and its presentation, an effective management plan is needed through an innovative approach both internally and externally to the restaurant (Alawamleh et al., 2018).

Based on the foregoing, a hypothesis is made:

H9: Organization innovation has effect on organization performance.

The influence of knowledge management with organization performance mediated by organization innovation. Innovation can occur as a result of combining new knowledge with existing knowledge by reconfiguring the capabilities and competencies of restaurant management in producing added value products, this includes processes related to the process of creating and acquiring new knowledge by integrating in the knowledge pool. , share it and apply it in value-added output for the taste of cuisine (Al-Sa'di et al., 2017). Furthermore, it can be said that there is a role for knowledge management in facilitating and improving food innovation and processes for organization performance (Al-Sa'di et al., 2017). It turns out that to improve organization performance there is a role for product and process innovation so that it becomes a mediation between knowledge 
management and organization performance (Cabrilo and Dahms, 2018). In improving organization performance, restaurant business management must focus on process innovation and service to customers (Al-Sa'di et al., 2017).

Based on the foregoing, a hypothesis can be made:


organization innovation.

The influence of competitive intensity with organization performance mediated by organization innovation. Competitive intensity experienced by restaurant management can be overcome through innovation to avoid technological obsolescence and anticipate market changes (Abebe and Angriawan, 2014). For this reason, restaurant management can utilize resources in the form of experience and accumulated knowledge to carry out organizational innovation so that it can avoid the risk of loss and uncertainty (Idarraga and Marin, 2019). Restaurant management strives to produce high innovation in order to achieve a sustainable competitive intensity against its competitors, so as to produce optimal organization performance (Haryanto et al., 2019).

Based on the foregoing, a hypothesis can be made:

H11: Competitive intensity has effect on organization performance mediated by organization innovation.

Influence dynamic capabilities with organization performance mediated by organization innovation. Service activities for restaurant customers that are determined by restaurant management based on the dominant orientation of restaurant service innovation that are supported by fully technological capabilities can mediate the relationship between dynamic capabilities and organization performance (Wilden and Gudergan, 2017).

Based on the foregoing, a hypothesis can be made:

H12: Dynamic capabilities has effect on organization performance mediated by organization innovation.

The influence of organizational slack with organization performance mediated by organization innovation. Organizational slack is all the resources owned by restaurant management to meet the demands of sub-units in the organization that require additional resources to complete the tasks set by management (Idarraga and Marin, 2019). Organizational slack is an excess of resources owned by restaurant management to fulfill service to restaurant customers because it responds to internal organizational pressure, in accordance with changes in strategy. For this reason, in facing environmental forces that have an impact on the organization, organization slack can be used to increase organization performance (Idarraga and Marin, 2019).

Based on the foregoing, a hypothesis can be made:

H13: Organizational slack has effect on organization performance mediated by organization innovation. 


\section{METHODS}

This study uses primary data with a survey method, where the researcher wants to know what the respondent thinks, by giving closed questions on the questionnaire. Data collection for the questionnaire was carried out by distributing questionnaires around the Jakarta, Surabaya, Semarang, Bandung, Tangerang and Bekasi areas according to predetermined criteria, namely 421 restaurant business managers (both local and international cuisine restaurants) in the Jakarta, Surabaya, Semarang, Bandung, Tangerang and Bekasi. In this case the population refers to who will be involved in the research process from all members of the group in the population.

Table 1. Operational Definitions and Variables

\begin{tabular}{|c|c|c|c|c|}
\hline Variable & Definition & Indicator & Scale & Source \\
\hline $\begin{array}{l}\text { Knowledge } \\
\text { Management } \\
(\mathrm{KM})\end{array}$ & $\begin{array}{l}\text { The knowledge needed by } \\
\text { restaurant management is } \\
\text { based on the information } \\
\text { sources obtained }\end{array}$ & $\begin{array}{l}\text { 1. Knowledge Acquisition } \\
\text { 2. Knowledge Conversion } \\
\text { 3. Knowledge Application } \\
\text { 4. Managerial Commitment } \\
\text { 5. Shared Vision } \\
\text { 6. Openness\&Experimentati } \\
\text { on } \\
\text { 7. Dialog } \\
\text { 8. Knowledge } \\
\text { Reciprocation } \\
\text { 9. Quality of Knowledge } \\
\text { Shared }\end{array}$ & Ordinal & $\begin{array}{l}\text { Turulja\& } \\
\text { Bajgoric } \\
\text { (2018) } \\
\text { Ganguly } \\
\text { et.al, } \\
(2019)\end{array}$ \\
\hline $\begin{array}{l}\text { Competitive } \\
\text { Intensity (CI) }\end{array}$ & $\begin{array}{l}\text { Restaurant management uses } \\
\text { its abilities to face very } \\
\text { competitive competition }\end{array}$ & $\begin{array}{l}\text { 1. Price Competition } \\
\text { 2. Operational Competition } \\
\text { 3. Increase Competition }\end{array}$ & Ordinal & $\begin{array}{l}\text { Idarraga } \\
\text { \& Marin } \\
(2019)\end{array}$ \\
\hline $\begin{array}{l}\text { Dynamic } \\
\text { Capabilities } \\
\text { (DC) }\end{array}$ & $\begin{array}{l}\text { The ability of restaurant } \\
\text { management to make } \\
\text { improvements in an } \\
\text { environment full of } \\
\text { uncertainty and can use its } \\
\text { resources to create an } \\
\text { innovation }\end{array}$ & $\begin{array}{l}\text { 1. Sense } \\
\text { 2. Seize } \\
\text { 3. Reconfigure }\end{array}$ & Ordinal & $\begin{array}{l}\text { Labanauskè } \\
\& \\
\text { Nedzinskas } \\
(2017)\end{array}$ \\
\hline $\begin{array}{l}\text { Prganizational } \\
\text { lack (ORS) }\end{array}$ & $\begin{array}{l}\text { Resources owned and used by } \\
\text { restaurant management to } \\
\text { complete company tasks }\end{array}$ & $\begin{array}{l}\text { 1. Strategic Decisions } \\
\text { 2. Long-term Plan } \\
\text { 3. Administrative Policy }\end{array}$ & Ordinal & $\begin{array}{l}\text { Idarraga \& } \\
\text { Marin } \\
(2019)\end{array}$ \\
\hline $\begin{array}{l}\text { Organizational } \\
\text { Innovation }(\mathrm{OI})\end{array}$ & $\begin{array}{l}\text { Innovating in the customer } \\
\text { service process by } \\
\text { restaurant management }\end{array}$ & $\begin{array}{l}\text { 1. Innovation Capability } \\
\text { 2. Tacit Knowledge Sharing } \\
\text { 3. Social Capital Relational } \\
\text { 4. Social Capital Cognitive } \\
\text { 5. Social Capital Structure }\end{array}$ & Ordinal & $\begin{array}{l}\text { Ganguly } \\
\text { et.al, } \\
(2019)\end{array}$ \\
\hline $\begin{array}{l}\text { Organizational } \\
\text { Performance (OP) }\end{array}$ & $\begin{array}{l}\text { The level of success that } \\
\text { has been achieved by } \\
\text { restaurant management }\end{array}$ & $\begin{array}{l}\text { Organizational } \\
\text { Business Performance }\end{array}$ & Ordinal & $\begin{array}{l}\text { Turulja } \\
\& \\
\text { Bajgoric } \\
(2018)\end{array}$ \\
\hline
\end{tabular}

Source: (Primary data, 2020) 


\section{RESULTS}

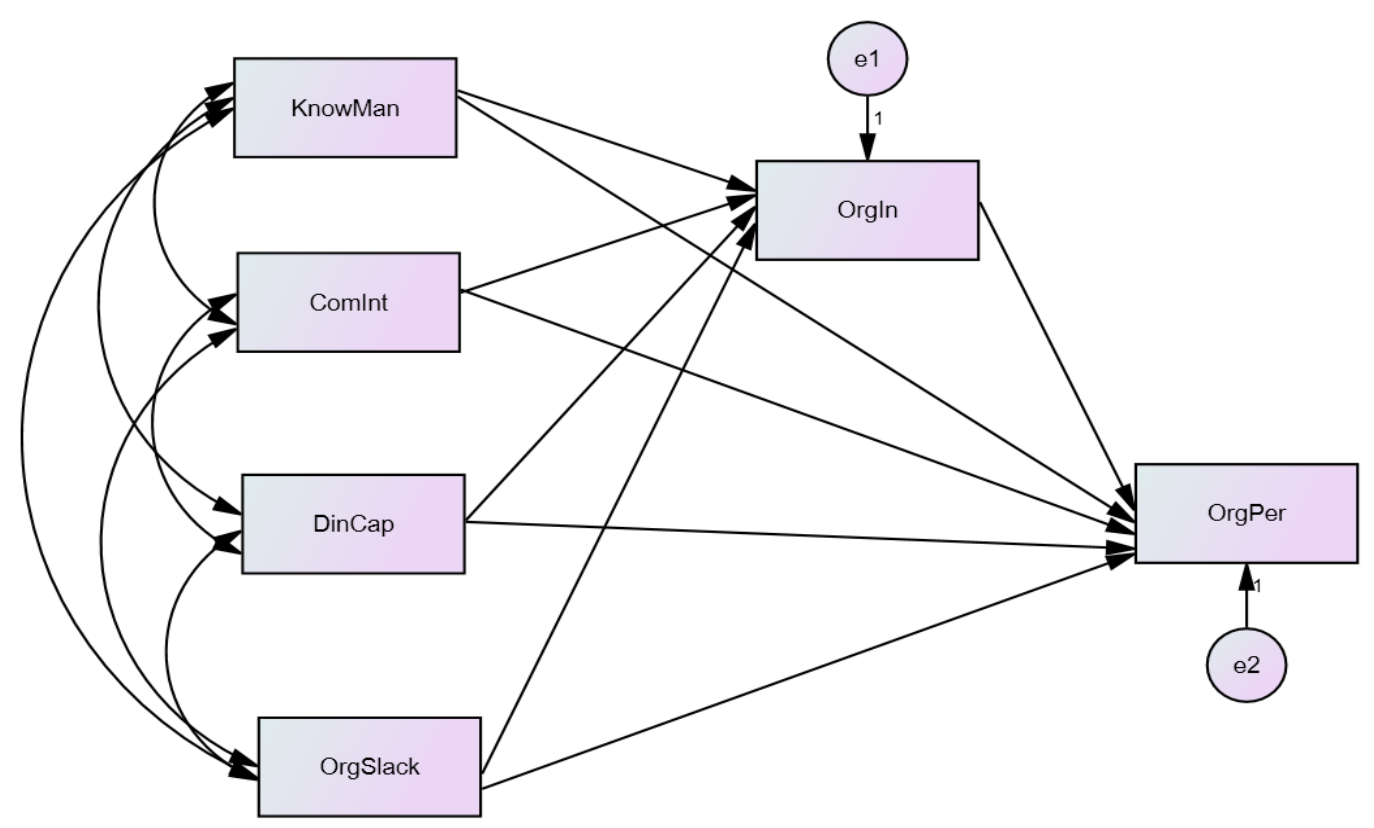

Figure 3. Non Full SEM model with AMOS

Source: (Research model, 2020)

The variables studied were knowledge management, competitive intensity, dynamic capabilities, organizational slack as an independent variable, organization innovation as a mediating variable and organization performance as the dependent variable.

Table 2. Validity and Reliability Test Results

\begin{tabular}{|c|c|c|c|}
\hline Variable & $\begin{array}{c}\text { Number } \\
\text { of } \\
\text { Indicators } \\
\end{array}$ & Indicator delete & $\begin{array}{c}\text { Valid Indicator } \\
\text { and Reliable } \\
\text { Indicator } \\
\end{array}$ \\
\hline \multicolumn{4}{|l|}{ Knowledge Management (KM) } \\
\hline Dimension : Knowledge Acquisition & 5 & $2(\mathrm{KCA} 2, \mathrm{KCA} 4)$ & 3 \\
\hline Dimension: Knowledge Conversion & 4 & $2(\mathrm{KC} 1, \mathrm{KC} 2)$ & 2 \\
\hline Dimension : Knowledge Application & 4 & $1(\mathrm{KAP} 1)$ & 3 \\
\hline Competitive Intensity (CI) & 3 & $1(\mathrm{CI} 1)$ & 2 \\
\hline \multicolumn{4}{|l|}{ Dynamic Capabilities (DC) } \\
\hline Dimension : Sense & 4 & $1(\mathrm{SE} 1)$ & 3 \\
\hline Dimension : Seize & 5 & $2(\mathrm{SZ} 1, \mathrm{SZ} 3)$ & 3 \\
\hline Dimension : Reconfigure & 4 & $1(\mathrm{RC} 3)$ & 3 \\
\hline Organizational Slack (OS) & 3 & 1 (ORS2) & 2 \\
\hline \multicolumn{4}{|l|}{ Organization Innovation (OI) } \\
\hline Dimension : Innovation Capability & 6 & 2 (ICP4, ICP6) & 4 \\
\hline Dimension : Tacit Knowledge Sharing & 7 & $2(\mathrm{TCS} 2, \mathrm{TCS} 4)$ & 5 \\
\hline Dimension : Social Capital Relational & 6 & - & 6 \\
\hline
\end{tabular}




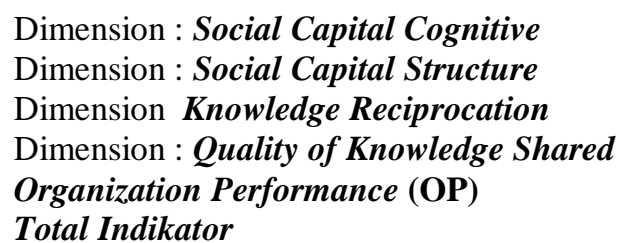

Source: (Processed data, 2020)

Validity and reliability testing for knowledge management variables which consists of 3 dimensions, namely knowledge acquisition, knowledge conversion and knowlodge application, results in conclusions from 13 measurement indicators that only 8 indicators are valid and reliable while 5 indicators must be removed because they are invalid and reliable as can be seen in the table .

Validity and reliability testing for competitive intensity variable which consists of 3 indicators, only 2 indicators are valid and reliable while 1 indicator must be removed because it is invalid.

Testing the validity and reliability of the dynamic capabilities variable which consists of 3 dimensions with 13 measurement indicators results in the conclusion that only 9 indicators are valid and reliable while the other 4 indicators must be removed as shown in Table 2.

The results of the validity and reliability testing for organizational slack variables which consist of 3 indicators which result in the conclusion that only 2 indicators are valid and reliable while 1 other indicator must be removed as shown in table 2.

Validity and reliability testing for organizational innovation variables which consist of 7 dimensions with 40 measurement indicators, only 31 indicators that are valid and reliable so that there are 9 indicators that must be eliminated as shown in Table 2.

Testing the validity and reliability for the organization performance variable which consists of 5 indicators results in a conclusion that only 3 indicators are valid and reliable where 2 indicators must be removed as can be seen in table 2 .

Table 3. Normality Test

\begin{tabular}{lrrrrrr}
\hline Variable & min & max & skew & c.r. & kurtosis & c.r. \\
\hline OrgSlack & 3.000 & 5.000 & -.868 & -7.267 & .593 & 2.484 \\
DinCap & 3.889 & 5.000 & -.192 & -1.612 & -1.017 & -4.262 \\
ComInt & 3.500 & 5.000 & -.071 & -.595 & -.968 & -4.054 \\
KnowMan & 3.889 & 5.000 & -.125 & -1.048 & -.566 & -2.370 \\
OrgIn & 3.864 & 5.000 & .097 & .809 & -.085 & -.357 \\
OrgPer & 3.667 & 5.000 & -.031 & -.263 & -.910 & -3.812 \\
Multivariate & & & & & -3.218 & -3.370 \\
\hline Source: (Processed data, 2020) & & & &
\end{tabular}

Based on table 3 for Normality Test results showing the value of critical ratio skewness of organizational slack indicator variable is -7.267 , dynamic capabilities is 1.612 , competitive intensity is -0.595 , knowledge management is -1.048 , organization innovation is 0.809 , organization performance is -0.263 . For the value of normal critical ratio skewness must show the results with $\mathrm{CR}$ value is (-/+) 2.58. Multivariate kurtosis value was obtained at -3.218 with a Critical Ratio of -3.370 . 


\section{The Research Findings of the Non Full SEM Model}

Table 4. Goodness of Fit Test

\begin{tabular}{lccc}
\hline \multicolumn{1}{c}{ Goodness of fit index } & $\begin{array}{c}\text { Criteria } \\
\text { (cut-off value) }\end{array}$ & Result & Conclusion \\
\hline $\mathrm{X}^{2}$ - Chi-square & expected small & 0.000 & \\
Significance probability & $\geq 0,05$ & -- & \\
RMSEA & $\leq 0,10$ & 0.185 & Marginal Fit \\
GFI & $\geq 0,90$ & 1.000 & Perfect fit \\
IFI & $\geq 0,90$ & 1.000 & Perfect fit \\
NFI & $\geq 0,90$ & 1.000 & Perfect fit \\
TLI & $\geq 0,90$ & - & \\
CF I & $\geq 0,90$ & 1.000 & Perfect fit \\
\hline
\end{tabular}

Source: (Processed data, 2020)

Processing results for the fit model after removing 7 outlier data so that the sample becomes 421 by doing is shown in the following table. The test results show that the 4 indicators produce a perfect fit model, namely GFI, IFI, NFI and CFI with a perfect value of 1 , while the RMSEA fit model indicator results in a conclusion that the model is not fit and for the chi-square indicator it produces a value of 0 so that the probability cannot be defined.

Table 5. Research Hypothesis Testing

\begin{tabular}{|c|c|c|c|c|c|}
\hline $\mathrm{H}_{1}$ & $\begin{array}{l}\text { Knowledge management has effect } \\
\text { on organization innovation }\end{array}$ & 0.014 & 0.360 & 0.359 & Not supported \\
\hline $\mathrm{H}_{2}$ & $\begin{array}{l}\text { Competitive intensity has effect on } \\
\text { organization innovation }\end{array}$ & -0.056 & -2.044 & 0.020 & Not supported \\
\hline $\mathrm{H}_{3}$ & $\begin{array}{l}\text { Dynamic capabilities has effect on } \\
\text { organization innovation }\end{array}$ & 0.064 & 1.597 & $0.055^{*}$ & Supported \\
\hline $\mathrm{H}_{4}$ & $\begin{array}{l}\text { Organizational slack has effect on } \\
\text { organization innovation }\end{array}$ & -0.026 & -1.181 & 0.119 & Not supported \\
\hline $\mathrm{H}_{5}$ & $\begin{array}{l}\text { Knowledge management has effect } \\
\text { on organization performance }\end{array}$ & 0.071 & 1.147 & 0.125 & Not supported \\
\hline $\mathrm{H}_{6}$ & $\begin{array}{l}\text { Competitive intensity has effect on } \\
\text { organization performance }\end{array}$ & $0-.034$ & -0.794 & 0.213 & Not supported \\
\hline $\mathrm{H}_{7}$ & $\begin{array}{l}\text { Dynamic capabilities has effect on } \\
\text { organization performance }\end{array}$ & -0.027 & -0.437 & 0.331 & Not supported \\
\hline $\mathrm{H}_{8}$ & $\begin{array}{l}\text { Organizational slack has effect on } \\
\text { organization performance }\end{array}$ & 0.092 & 2.699 & $0.003 * *$ & Supported \\
\hline
\end{tabular}




\begin{tabular}{|c|c|c|c|c|c|}
\hline $\mathrm{H}_{9}$ & $\begin{array}{l}\text { Organization innovation has effect on } \\
\text { organization performance }\end{array}$ & 0.743 & 9.884 & $.0 .00 * *$ & Supported \\
\hline $\mathrm{H}_{10}$ & $\begin{array}{l}\text { Knowledge management has effect on } \\
\text { organization performance mediated } \\
\text { by organization innovation }\end{array}$ & $\begin{array}{c}0.014 * 0.743 \\
= \\
0.0103\end{array}$ & 0.349 & 0.363 & Not supported \\
\hline $\mathrm{H}_{11}$ & $\begin{array}{l}\text { Competitive intensity has effect on } \\
\text { organization performance mediated } \\
\text { by organization innovation }\end{array}$ & $\begin{array}{c}- \\
0.056^{*} 0.743 \\
= \\
-0.0416\end{array}$ & -2.030 & 0.021 & Not supported \\
\hline $\mathrm{H}_{12}$ & $\begin{array}{l}\text { Dynamic capabilities has effect on } \\
\text { organization performance mediated } \\
\text { by organization innovation }\end{array}$ & $\begin{array}{l}0.064 * 0.743 \\
= \\
0.0475\end{array}$ & 1.579 & $0.057 *$ & Supported \\
\hline $\mathrm{H}_{13}$ & $\begin{array}{l}\text { Organizational slack has effect on } \\
\text { organization performance mediated } \\
\text { by organization innovation }\end{array}$ & $\begin{array}{c}- \\
0.026 * 0,743 \\
= \\
0.0193\end{array}$ & -1.173 & 0.120 & Not supported \\
\hline
\end{tabular}

*=alpha $10 \% \quad * *=$ alpha $5 \%$

Source: (Processed data, 2020)

The results of hypothesis testing are proven to have 4 hypotheses that have a positive influence on dynamic capabilities towards organization innovation with an alpha of $10 \%$, a positive effect of organization slack on organization performance with an alpha of 5\%, a positive effect of organization innovation on organizational performance with an alpha of 5\% and a positive influence dynamic capabilities to organization performance mediated by organization innovation with alpha 10\%. As for the other 9 hypothesis testing, the hypothesis was not proven.

\section{DISCUSSION}

Organization performance variable which consists of 5 indicators results in a conclusion that only 3 indicators are valid and reliable, namely the rate of return on investment (OP1), profitable (OP3) and earning a profit (OP4).

competitive intensity variable which consists of 3 indicators, only 2 indicators are valid and reliable, namely increase competition (CI2) and operational competition (CI3).

Dynamic capabilities variable which consists of 3 dimensions with 13 measurement indicators results in the conclusion that only 9 indicators are valid and reliable, namely the training \& skills (SE2), performance appraisal (SE3), work environment assessment (SE4), organizational design (SZ2), organizational planning (SZ4), resolution (SZ5), regeneration ( $\mathrm{RC} 1)$, decentralization \& co-specialization ( $\mathrm{RC} 2)$, transfer knowledge (RC4).

Organizational slack variables which consist of 3 indicators which result in the conclusion that only 2 indicators are valid and reliable, namely the strategic decisions (ORS1), administrative policy (ORS3). organizational innovation variables which consist of 7 dimensions with 40 measurement indicators, only 31 indicators that are valid and reliable, namely the introduction of new products (ICP1), sales of new products (ICP2), organizational creativity (ICP3), product development (ICP5), innovation of opinions 
(TCS1), implementing thinking results (TCS3), conducting discussions about ideas (TCS5), share work experiences (TCS6), recognize colleagues well (TCS7), trusted (SCR1), have passion (SCR2), have integrity (SCR3), trust each other (SCR4), respect each other (SCR5), cooperate (SCR6), vision (SCC1), have commitment (SCC3), common goals (SCC5), cohesive team work (SCS1), good communication (SCS2), good working relationship (SCS6), sharing new ideas (KR1), good response (KR2), good communication (KR3), help each other (KR4), complete \& clear (QKS1), accurate (QKS2), on time (QKS3), easy to understand (QKS4), relevant (QKS5), reliable (QKS6). knowledge management variables which consists of 3 dimensions, namely knowledge acquisition, knowledge conversion and knowlodge application, results in conclusions from 13 measurement indicators that only 8 indicators are valid and reliable, namely the knowledge about suppliers (KCA1), exchanging information (KCA3), conducting comparisons (KCA5), integrating knowledge (KC3), changing knowledge (KC4), applying knowledge in uncertain situations (KAP2), good access to information (KAP3), can solve problems (KAP4).

The results of hypothesis testing are proven to have 4 hypotheses that have a positive influence on dynamic capabilities towards organization innovation, a positive effect of organization slack on organization performance, a positive effect of organization innovation on organizational performance and a positive influence dynamic capabilities to organization performance mediated by organization innovation. In this case, restaurant management needs to strive for high innovation in order to gain a sustainable competitive advantage against its competitors, so that the organization can produce optimal organization performance which in turn can expand the local market base and be improved for certain local preferences. This indicates that customers have more alternatives for choosing a product or service. As competition increases, companies experience strong pressure toward cost efficiency and lower prices, resulting in narrower profit margins and a more limited slack in the organization. In such conditions, innovation is needed, namely by means of continuous improvements to products, services, and processes needed to face competition. Dynamic capabilities as a restaurant management routine must be able to create, expand or modify existing resources using its strategies so that the managed restaurant will get new resources, so that the restaurant can make these resources more valuable. The strategy that can be carried out by restaurant management is to collaborate with the Provincial Government by striving for high innovation in order to achieve a sustainable competitive advantage, resulting in optimal organization performance which in turn can expand the local market base and be improved for certain local preferences in environmental conditions full of uncertainty in organization slack.

\section{CONCLUSION}

Restaurant management only has a positive effect of dynamic capabilities on organization innovation with an alpha of $10 \%$, the positive influence of organization slack on organization performance with an alpha of 5\%, the positive influence of organization performance on organization performance with an alpha of 5\% and the positive influence of dynamic capabilities on organization. Performance mediated by organization innovation with an alpha of $10 \%$. In this case, restaurant management on average needs to prepare for leadership regeneration in organizations, decentralization and co-specialization 
in organizations, reforming organizational resources, improving technology and intellectual property rights, commercializing the results of $R \& D$ and innovation (transfer of knowledge and technology, intellectual property protection).

The test results show that the 4 indicators produce a perfect fit model, namely GFI, IFI, NFI and CFI with a perfect value of 1, while the RMSEA fit model indicator results in a conclusion that the model is not fit and for the chi-square indicator it produces a value of 0 so that the probability cannot be defined.

In general, of the 77 indicators used to measure the 6 variables used in the study, 55 indicators proved valid and reliable while 22 indicators had to be removed because they were invalid and reliable.

Future Research. There are suggestions for future research: (1) The location of the research object can be done in other areas. (2) The variables used in this study can be added variables: taste and lifestyle of the community.

\section{REFERENCES}

Abdullah, I., Rashid, Y. and Umair, T. (2013). Effect of organizational learning and knowledge management practices on organizational performance. Journal of Basic and Applied Scientific Research, 3(5): 34-39.

Abebe, M.A., and Angriawan, A. (2014). Organizational and competitive influences of exploration and exploitation activities in small firms. Journal of Business Research, 67(3):339-345.

Alawamleh, M., Ismail, L.B., Aladwan, K. and Saleh, A. (2018). The influence of open/closed innovation on employees' performance. International Journal of Organizational Analysis, 26(1):75-90.

Alsabbagh, M. and Khalil, A.H.A. (2017). The impact of knowledge management on organizational learning (An empirical study on the education sector in Damascus city). International Journal of Academic Research in Business and Social Sciences, 7(4): 560-578.

Al-Sa'di, A.F., Abdallah, A.B. and Dahiyat, S.E. (2017). The mediating role of product and process innovations on the relationship between knowledge management and operational performance in manufacturing companies in Jordan. Business Process Management Journal, 23(2):349-376.

Cabrilo, S. and Dahms, S. (2018). How strategic knowledge management drives intellectual capital to superior inovation and market performance. Journal of Knowledge Management, 22(3):621-648.

Ganguly, A., Talukdar, A. and Chatterjee, D. (2019). Evaluating the role of social capital, tacit knowledge sharing, knowledge quality and reciprocity in determining innovation capability of an organization. Journal of Knowledge Management, 23(6):1105-1135.

Haryanto, A.T., Dewi, S.N. and Triono, B.R.M.S. (2019). Marketing and competitive advantages. Jurnal Perilaku dan Strategi Bisnis, 7(2):115-123.

https://lifestyle.okezone.com/accessed : August, 2020.

https://www.posist.com/restaurant-times/restro-gyaan/9-essential-traits-successfulrestaurant.html/2020/accessed : July, 2020. 
Idarraga, D.A.M. and Marin, J.C.C. (2019). Relationship between innovation and performance : Impact of competitive intensity and organizational slack. RAE-Revista de Administração de Empresas (Journal of Business Management), 59(2):95-107.

King, W.R. (2009). Knowledge management and organizational learning. Annals of Information System, 4.

Kumaravel, V. and Vikkraman, P. (2018). Assessment of knowledge management practices in higher educational institutions in India: A Structural Equation Modeling approach. Int Journal Education Science, Taylor \& Francis, 20(1-3):120-136.

Labanauské, K.B. and Nedzinskas, S. (2017). Dynamic capabilities and their impact on research organizations' R\&D and innovation performance. Journal of Modelling in Management, 12(4):603-630.

Mutahar, A. M., Daud, N. M., Ramayah, T., Putit, L., and Isaac, O. (2017). Examining the Effect of Subjective Norms and Compatibility as External Variables on TAM: Mobile Banking Acceptance in Yemen. Science International, 29(4), 769-776.

Najmi, K., Kadir, A.R. and Kadir, M.I.A. (2018). Mediation effect of dynamic capability in the relationship between knowledge management and strategic leadership on organizational performance accountability. International Journal of Law and Management, 60(2):517-529.

Ngoc-Tan, N. and Gregar, A. (2018). Impact of knowledge management on innovation in higher education institutions : An empirical evidence from Vietnam. Economics and Sociology, 11(3):301-320.

Shiferaw, B., and Molla, T. (2018). Does behavior of clients matter in adoption of internet banking? Evidence from Commercial Bank of Ethiopia. Journal of Economics and International Finance, 10(6), 58-64.

Turulja, L. and Bajgoric, N. (2018). Knowing means existing : Organizational learning dimensions and knowledge management capability. Business System Research, 9(1):1-18.

Wilden, R. and Gudergan, S. (2017). Service-dominant orientation, dynamic capabilities and firm performance. Journal of Service Theory and Practice, 27(4):808-832.

Wu, Y., Wei, Z., and Liang, Q. (2011). Top management team diversity and strategic change : The moderating effects of pay imparity and organization slack. 24(3), 267281. 